\title{
Heterogeneity of respiratory dendritic cell subsets and lymphocyte populations in inbred mouse strains
}

\author{
Holger Hackstein ${ }^{1 *}$, Andreas Wachtendorf ${ }^{1}$, Sabine Kranz ${ }^{1}$, Jürgen Lohmeyer ${ }^{2}$, Gregor Bein ${ }^{1}$ and Nelli Baal ${ }^{1}$
}

\begin{abstract}
Background: Inbred mouse strains are used in different models of respiratory diseases but the variation of critical respiratory leukocyte subpopulations across different strains is unknown.

Methods: By using multiparameter flow cytometry we have quantitated respiratory leukocyte subsets including dendritic cells subpopulations, macrophages, classical T and B cells, natural killer cells, $\gamma \delta T C R+T$ cells and lineage-negative leukocytes in the five most common inbred mouse strains BALB/C, C57BL/6, DBA/2, 129SV and $\mathrm{C} 3 \mathrm{H}$. To minimize confounding environmental factors, age-matched animals were received from the same provider and were housed under identical specific-pathogen-free conditions.
\end{abstract}

Results: Results revealed significant strain differences with respect to respiratory neutrophils ( $p=0.005$; up to 1.4 fold differences versus C57BL/6 mice), eosinophils ( $p=0.029$; up to 2.7 fold), certain dendritic cell subsets ( $\leq \leq 0.0003$; up to 3.4 fold), $T$ ( $p<0.001$; up to 1.6 fold) and B lymphocyte subsets ( $p=0.005$; up to 0.4 fold), $\gamma \delta$ T lymphocytes ( $p=0.003$; up to 1.6 fold $)$, natural killer cells ( $p<0.0001$; up to 0.6 fold) and lineage-negative innate leukocytes ( $\mathrm{p} \leq 0.007$; up to 3.6 fold). In contrast, total respiratory leukocytes, macrophages, total dendritic cells and bronchoalveolar lavage leukocytes did not differ significantly. Stimulation of respiratory leukocytes via Toll-like receptor 4 and 9 as well as CD3/CD28 revealed significant strain differences of TNF-a and IL-10 production.

Conclusion: Our study demonstrates significant strain heterogeneity of respiratory leukocyte subsets that may impact respiratory immunity in different disease models. Additionally, the results may help identification of optimal strains for purification of rare respiratory leukocyte subsets for ex vivo analyses.

\section{Introduction}

Pulmonary host defense is mediated by different types of immunocompetent leukocytes including classical $\mathrm{T}$ and $\mathrm{B}$ lymphocytes, innate lymphocytes (NK cells, $\gamma \delta \mathrm{T}$ cells), professional antigen presenting cells (macrophages, dendritic cells) and granulocytes. Recent evidence indicates that these cells are not only stimulators of immunity and inflammation but additionally regulate immune responses and exhibit anti-inflammatory activity. Many respiratory immune responses result in tolerance to subsequent antigen challenge, which is mediated by Foxp3+ regulatory $\mathrm{T}$

\footnotetext{
* Correspondence: Holger.Hackstein@immunologie.med.uni-giessen.de 'Institute for Clinical Immunology and Transfusion Medicine, Justus-Liebig-University Giessen, Member of the German Center for Lung Research, Langhansstr 7, D-35390, Giessen, Germany

Full list of author information is available at the end of the article
}

(Treg) cells interacting with professional antigen presenting cells [1].

Dendritic cells (DC) are rare professional antigen presenting cells playing critical roles as initiators and regulators of innate and adaptive immunity [2-4]. In the murine respiratory tract, distinct DC subsets have been identified $[5,6]$. These respiratory DC subsets form an interdigitating network of cells being specialized for different immunological functions in the respiratory tract. Respiratory DC can be separated based on the expression of different surface markers in at least four major subsets: plasmacytoid DC (pDC), CD103 ${ }^{+} \mathrm{DC}, \mathrm{CD} 103^{\text {neg }}$ $\mathrm{CD}_{11} \mathrm{~b}^{\text {high }}$ MHC-class-II ${ }^{\text {high }}$ DC $\left(\mathrm{CD} 11 \mathrm{~b}^{\text {high }} \mathrm{DC}\right)$ and $\mathrm{CD}_{103}{ }^{\text {neg }} \mathrm{CD} 11 \mathrm{~b}^{+}$MHC-class-II ${ }^{\text {neg-med }}$ monocytic DC (MoDC)[5,7]. Respiratory pDC are not only involved in limitation of viral respiratory infection [8] but additionally prevent airway hyperresponsiveness both after

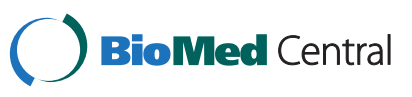


infection [9] and after inhalation of harmless antigens [10]. CD $103^{+}$DC have been described to express high levels of the Langerhans cell marker langerin and were increased in mice with airway hyperresponsiveness and eosinophilia suggesting a role in allergen-induced respiratory inflammation [11] With respect to adaptive $\mathrm{T}$

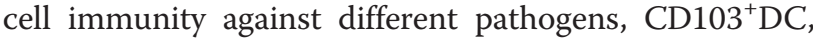
CD11b $b^{\text {high }} \mathrm{DC}$ and MoDC have been identified as major migratory subsets presenting antigens in the draining lymph nodes to naïve $\mathrm{CD}^{+}$and $\mathrm{CD}^{+} \mathrm{T}$ cells [5,12-15].

Although respiratory DC are central for regulation of lung immunity [16] they closely interact with respiratory $\mathrm{T}$ and $\mathrm{B}$ cells, innate lymphocytes, such as natural killer (NK) cells and $\gamma \delta \mathrm{TCR}^{+} \mathrm{T}(\gamma \delta \mathrm{T})$ cells and myeloidderived leukocytes, such as respiratory macrophages and granulocytes.

So far, most of the studies have been focused on selected subsets of respiratory leukocytes and a complete analysis including all mentioned subsets is still lacking. Moreover, it is not clear whether different inbred mouse strains with a different genetic background exhibit differences in the respiratory frequencies of these functionally relevant leukocyte subsets. Given the fact, that inbred mouse strains are known for their marked variation of susceptibility and resistance against various pathogens we hypothesized that inbred mouse strains are likely to exhibit major differences of respiratory leukocyte subset frequencies. In this study we have enumerated the major respiratory leukocyte subsets including DC subpopulations, innate and adaptive lymphocytes, respiratory macrophages and granulocytes in the five most common inbred mouse strains $\mathrm{C} 57 \mathrm{BL} / 6, \mathrm{BALB} / \mathrm{c}, \mathrm{C} 3 \mathrm{H}, \mathrm{DBA} / 2$ and 129SV. Additionally, since increasing evidence suggest an important role of innate lineage-negative (lin ${ }^{\text {neg }}$ ) leukocytes in immunity $[17,18]$ we also quantitated the frequencies of respiratory $\operatorname{lin}^{\text {neg }}$ leukocytes. The results indicate marked differences in the frequencies of respiratory DC subsets, innate and classical lymphocytes and innate lin ${ }^{\text {neg }}$ leukocytes providing additional insight into the heterogeneity of inbred mouse strains.

\section{Material and methods \\ Mice}

Specific-pathogen-free mice, BALB/c (Balb/cAnNCrl), C57BL/6 (C57BL/6NCrl), DBA/2 (DBA/2NCrl), 129SV (129S2/SVPasCrl) and C3H (C3H/HeNCrl), 7-11 weeks of age were purchased from Charles River, Sulzfeld, Germany and maintained under specific-pathogen-free conditions. The $\mathrm{C} 3 \mathrm{H}$ mice do not carry the TLR4 $4^{\mathrm{LPS}-\mathrm{d}}$ mutation and are therefore LPS sensitive. Analyses were performed after approval of the regional authority board (animal ethics Giessen A2/2011).

\section{Lung preparation}

Lung single cell suspension were prepared after enzymatic digestion as described in detail elsewhere [5] with minor modifications. Briefly, mice were euthanized and lungs were perfused via the right ventricle with HBSS (PAA, Germany) to remove the intravascular pool of cells. Tissues were minced and digestion was performed in $0.09 \mathrm{U} / \mathrm{ml}$ type A collagenase (Roche, Germany) and $9.09 \mathrm{U} / \mathrm{ml}$ DNase (Roche, Germany) in IMDM (PAA, Germany) with 10\% FCS (PAA, Germany) at $37^{\circ} \mathrm{C}$ for $1 \mathrm{~h}$. Single cell suspension were prepared by tissue resuspension with 20 G $11 \frac{1}{2}$ canules (0.9 x $40 \mathrm{~mm}$; BD, Germany) and by mashing through a $70 \mu \mathrm{M}$ cell strainer (BD, Germany). Red blood cells were lysed by ammoniumchloride lysis. Cells were washed with HBSS for flow cytometry staining or leukocytes were magnetic-bead sorted after washing with $\mathrm{PBS} / 2 \% \mathrm{BSA} / 2 \mathrm{mM}$ EDTA (PAA, Germany). Bronchoalveolar lavages (BAL) were performed as described elsewhere [19]. In order to assess whether lung preparations of inbred mouse strains contained different total CD45+ leukocyte numbers we used the trucount method (BD Biosciences, Germany) to enumerate absolute leucocyte counts per lung preparation. The tubes contain a known number of fluorescent beads allowing the flow cytometer software to calculate absolute cell counts.

\section{Flow cytometry and staining procedure}

Cellular phenotyping was performed on a FACS CantoII flow cytometer (Becton Dickinson, San Jose, CA, USA). The following fluorochrome-labelled monoclonal antibodies conjugated to FITC, PE, PeCy7, PerCPCy5.5, APC, APC-Cy7, Pacific Blue and appropriate isotype controls were used for surface staining according to the manufacturer's instructions: CD3e, CD4, CD8a, CD11b, CD11c, CD19, CD25, CD45, CD49b, CD90, CD103, CD127, TCR- $\gamma \delta$, I-A/I-E-, GR1, F4/80 (all mabs from Biolegend, Germany), CD39, Foxp3 (eBioscience, Germany), Siglec-F (BD Biosciences, Germany) and 120g8 (Dendritics, France). The lineage cocktail consisted of the following mAbs: CD3e (BD Pharmingen, Germany), CD4, CD8a, CD11b, CD11c, CD19, B220, TER-119, FceR1 (all from Biolegend, Germany). Autofluorescent respiratory macrophages were identified through Siglec-F expression.

A detailed list of mabs panels and fluorochrome combinations is summarized in Table 1 (Table 1). Isotype matched control antibodies were ordered from the same company. Isotype controls were used to control specificity of staining of lineage markers and as fluorescence minus one (FMO) controls to control for specificity of complex subset markers or during intracellular stainings. Surface $\mathrm{mAb}$ or isotype staining time was 30 
Table 1 Antibody panels with fluorochromes and $\mathrm{mAb}$ clones

\begin{tabular}{|c|c|c|c|c|c|c|c|c|c|c|c|}
\hline \multirow{2}{*}{$\begin{array}{l}\text { Panel } \\
\text { Lympho1 }\end{array}$} & & \multirow{2}{*}{$\frac{\text { FITC }}{\text { TCR gd }}$} & \multicolumn{2}{|c|}{ PE } & \multirow{2}{*}{$\begin{array}{l}\text { PE-Cy7 } \\
\text { CD4 }\end{array}$} & \multirow{2}{*}{$\begin{array}{l}\text { PerCP-Cy5.5 } \\
\text { CD19 }\end{array}$} & \multirow{2}{*}{$\frac{\text { APC }}{\text { CD8a }}$} & \multirow{2}{*}{$\begin{array}{l}\text { APC-Cy7 } \\
\text { CD45 }\end{array}$} & \multicolumn{3}{|l|}{ P-Blue } \\
\hline & antigen & & \multicolumn{2}{|c|}{ CD3e } & & & & & CD49b & & \\
\hline & clone & GL3 & \multicolumn{2}{|c|}{$145-2 C 11$} & GK 1.5 & 1D3 & $53-6.7$ & 30-F11 & DX5 & & \\
\hline & Cat.No. & 118106 & \multicolumn{2}{|c|}{100307} & 100406 & 551001 & 100712 & 103116 & 108918 & & \\
\hline & company & Bio-legend & \multicolumn{2}{|c|}{ Biolegend } & Biolegend & BDPharm. & Biolegend & Biolegend & Biolegen & & \\
\hline \multirow{4}{*}{$\begin{array}{l}\text { Lympho2/ } \\
\text { Lin-neg cells }\end{array}$} & antigen & Lin-cocktail & \multicolumn{2}{|c|}{ CD3e } & CD90.2 & CD4 & & CD45 & CD25 & & \\
\hline & clone & see & \multicolumn{2}{|c|}{$145-2 C 11$} & $53-2.1$ & GK 1.5 & & 30-F11 & eBio3C7 & & \\
\hline & Cat.No. & below & \multicolumn{2}{|c|}{100307} & 140310 & 100434 & & 103116 & $48-0253-8$ & & \\
\hline & company & & \multicolumn{2}{|c|}{ Biolegend } & Biolegend & Biolegend & & Biolegend & eBio-scier & & \\
\hline \multirow[t]{4}{*}{ DC } & antigen & $|-A /|-E$ & SiglecF & CD49b & CD11c & CD103 & pDC/IPC-A647 & CD45 & CD11b & & \\
\hline & clone & M5/114.15.2 & E50-2440 & DX5 & N418 & 2 E 7 & $120 \mathrm{~g} 8$ & 30-F11 & $\mathrm{M} 1 / 70$ & & \\
\hline & Cat.No. & 107606 & 562068 & 108908 & 117306 & 121416 & DDX039A647 & 103116 & 101224 & & \\
\hline & company & Bio-legend & \multicolumn{2}{|c|}{ Biolegend } & Biolegend & Biolegend & Dendritics & Biolegend & Biolegen & & \\
\hline Mono/ & antigen & I-A/I-E & \multicolumn{2}{|c|}{ SiglecF } & CD11C & CD11b & GR1 & CD45 & $\mathrm{F} 4 / 80$ & & \\
\hline \multirow[t]{3}{*}{ Granulo } & clone & M5/114.15.2 & \multicolumn{2}{|c|}{ E50-2440 } & N418 & $\mathrm{M} 1 / 70$ & RB6-8C5 & 30-F11 & BM8 & & \\
\hline & Cat.No. & 107606 & \multicolumn{2}{|c|}{562068} & 117306 & 550993 & 108412 & 103116 & 123124 & & \\
\hline & company & Bio-legend & \multicolumn{2}{|c|}{ Biolegend } & Biolegend & BD Pharm. & Biolegend & Biolegend & Biolegen & & \\
\hline \multirow[t]{4}{*}{ Tregs } & antigen & CD127 & \multicolumn{2}{|c|}{ CD39 } & CD3e & CD4 & Foxp3 & CD45 & CD25 & & \\
\hline & clone & A7R34 & \multicolumn{2}{|c|}{ 24DMS1 } & $145-2 c 11$ & GK1.5 & FJK-16s & 30-F11 & eBio3C7 & & \\
\hline & Cat.No. & 135009 & \multicolumn{2}{|c|}{$12-0391-82$} & 100320 & 100434 & $77-5775-40$ & 103116 & $48-0253-$ & & \\
\hline & company & Bio-legend & \multicolumn{2}{|c|}{ eBioscience } & Biolegend & Biolegend & eBioscience & Biolegend & eBio-scier & & \\
\hline \multirow{5}{*}{$\begin{array}{l}\text { LIneage } \\
\text { cocktail }\end{array}$} & & all FITC & & & & & & & & & \\
\hline & antigen & CD3e & CD4 & CD8a & CD45R/B220 & TER-119 & CD11b & CD11C & CD49b & FceR1 & CD19 \\
\hline & clone & $145-2 C 11$ & GK 1.5 & $53-6.7$ & RA3-6B2 & TER-119 & $\mathrm{M} 1 / 70$ & N418 & DX5 & MAR-1 & 6D5 \\
\hline & Cat.No. & 553058 & 100406 & 100706 & 103206 & 116206 & 101206 & 117306 & 108906 & 134306 & 115506 \\
\hline & company & BD Pharm & Biolegend & & & & & & & & \\
\hline
\end{tabular}

min on ice and cells were washed with staining buffer (1x PBS/5\% FBS; both reagents from PAA, Germany) at 400g, $5 \mathrm{~min}$, room temperature (RT) before analysis. For intracellular staining, samples were first stained for surface antigens, washed with permeabilization buffer (ebioscience, Germany) $5 \mathrm{~min}, \mathrm{RT}, 400 \mathrm{~g}$ and supernatant was discarded. Cell pellet was vortexed for dissociation and incubated with fixation/permeabilization buffer (anti mouse/rat Foxp3 staining set, ebioscience, Germany) $30 \mathrm{~min}$ on ice. $2 \mathrm{ml}$ of permeabilization buffer (eBioscience) was added directly to the pellet before centrifugation (400 g, $5 \mathrm{~min}, \mathrm{RT})$. Washing with permeabilization buffer was repeated once. Cells were resuspended in $100 \mu \mathrm{l}$ permeabilization buffer and intracellular mabs or isotype controls were added at the recommended concentrations and incubated $30 \mathrm{~min}$ on ice. Cells were washed two times with permabilization buffer and immediately analysed by flow cytometry. The number of acquired events was $\geq 500,000$ after surface or intracellular stainings.

\section{Cell culture experiments, reagents and cytokine} quantification

Lung leukocytes were magnet-bead purified using CD45 microbeads (Miltenyi Biotec, Germany) according to the manufacturer instruction (CD45 purity $>85 \%$ ). Viability of cells was $>90 \%$ as indicated by trypan blue staining. $2 \times 10^{5}$ respiratory leukocytes from different mouse strains were stimulated in 96-well plates (Greiner, Germany) with TLR4 agonist LPS ( $1 \mu \mathrm{g} / \mathrm{ml}$; E coli serotype 0111:B4 strain, Sigma Aldrich, Germany), TLR9 agonist CpG 1826 (3.1 $\mu \mathrm{M} / \mathrm{ml}$; Invivogen, France) for $24 \mathrm{~h}$ and $\mathrm{CD} 3 / \mathrm{CD} 28 \mathrm{mAb}$ ( $1 \mu \mathrm{g} / \mathrm{ml}$ each, Biolegend, Germany) for $48 \mathrm{~h}$ in RPMI 1640 medium supplemented with L-glutamine, penicillin/ streptomycin, 10\% heat-inactivated FCS (PAA Germany). Mouse TNF- $\alpha$, IFN- $\gamma$ and IL-10 were quantitated by ELISA (ElisaMax Standard Set, Biolegend, Germany).

\section{Statistical analyses}

The significance of differences between groups were analysed by one-way ANOVA and Tukey post-test for 
multiple comparisons. A p-value $<0.05$ was considered significant. Data are shown as means $( \pm$ SEM). Statistical analyses were performed with Prism 5.02 software (Graphpad software, Inc.).

\section{Results}

Inbred mouse strains exhibit similar numbers of total respiratory leukocytes, macrophages, DC, BAL but different granulocyte numbers

Respiratory leukocyte subsets were dissected in lung homogenate by multiparameter flow cytometry (Figure 1 ). After identification of leukocytes through $\mathrm{CD} 45+$, respiratory neutrophils were subsequently identified as GR $1^{\text {high }} \mathrm{CD} 11 b^{\text {high }}$, eosinophils as SiglecF ${ }^{+}$MHC-class$\mathrm{II}^{\text {neg }}$ and macrophages as SiglecF ${ }^{\text {high }} \mathrm{F} / 80^{+}$cells (Figure 1A). Total respiratory DC were identified as $\mathrm{CD}_{11 \mathrm{c}^{+}}$SiglecF $^{\text {neg }} \mathrm{CD}_{49 b^{\text {neg }}}$ leukocytes (Figure 1B). Results indicated that total respiratory leukocyte numbers do not differ significantly between common inbred mouse strains (Figure 2A). Accordingly, in subsequent analyses subset frequencies were quantitated in \% of leukocytes. Analysis of respiratory macrophages (Figure 2B), dendritic cells (Figure $2 \mathrm{C}$ ) and BAL numbers including BAL macrophages (Figure 2D, E) indicated similar results. In contrast, respiratory neutrophil (Figure 2F) numbers were elevated in $\mathrm{C} 3 \mathrm{H}$ and DBA mice and eosinophil (Figure 2G) numbers were elevated in $\mathrm{BALB} / \mathrm{c}$ mice. Magnitude of fold- differences for all leukocyte subsets in comparison to C57BL/6 mice is summarized in Table 2.

Significant differences of respiratory dendritic cell subsets across inbred mouse strains

Respiratory DC represent a heterogenous population of professional antigen presenting cells. Accordingly we performed 7-color flow cytometry to quantitate the four major DC subsets in different inbred mouse strains (Figure 3, Figure 4). Multicolour flow cytometry allowed us to separate four respiratory DC subpoulations, plasmacytoid DC (pDC; 120g8+, CD11c+, Siglec $F^{\text {neg }}, C D 49 b^{\text {neg }}$, CD45+), CD103+ DC (CD103+, 120g8 ${ }^{\text {neg }}$; CD11c+; Siglec $\left.F^{\text {neg }}, C D 49 b^{\text {neg }}, C D 45+\right)$ monocytic $D C$ (moDC; CD11b ${ }^{\text {high }}, M H C-I^{\text {med-low }}, C D 11 c+$; Siglec $F^{\text {neg }}, C D 49 b^{\text {neg }}$, $\left.\mathrm{CD} 103^{\text {neg }}, 120 \mathrm{~g} 8^{\text {neg }} \mathrm{CD} 45+\right)$, and $\mathrm{CD} 11 \mathrm{~b}^{\text {high }} \mathrm{DC}$ $\left(\mathrm{CD} 11 \mathrm{~b}^{\text {high }}, \mathrm{MHC}-\mathrm{II}^{\text {high }}, \mathrm{CD} 11 \mathrm{c}+\right.$; Siglec $\mathrm{F}^{\text {neg }}, \mathrm{CD} 49 \mathrm{~b}^{\text {neg }}$, $\left.\mathrm{CD} 103^{\text {neg }}, 120 \mathrm{~g} 8^{\text {neg }} \mathrm{CD} 45+\right) .129 \mathrm{SV}$ mice exhibited significantly elevated $\mathrm{pDC}$ and CD11b ${ }^{\text {high }} \mathrm{DC}$ numbers $(\mathrm{p}<0.001$ and $\mathrm{p}=0.0003$; Figure $4 \mathrm{~A}, \mathrm{D}$ ) when compared to $\mathrm{C} 57 \mathrm{BL} / 6$, $\mathrm{C} 3 \mathrm{H}, \mathrm{DBA}$ or $\mathrm{BALB} / \mathrm{c}$ mice. In contrast CD103+ DC and MoDC numbers were significantly elevated in $\mathrm{C} 3 \mathrm{H}$ mice when compared to $\mathrm{C} 57 \mathrm{BL} / 6, \mathrm{BALB} / \mathrm{c}$ or $\mathrm{DBA}$ strains $(p<0.01$; Figure $4 B, C)$. These results suggested significant strain heterogeneity of functional divergent DC subsets. 129SV mice can be characterized as rich in pDC and $\mathrm{CD}_{11} \mathrm{~b}^{\text {hi }}$ DC. In contrast, $\mathrm{C} 3 \mathrm{H}$ mice are rich in $\mathrm{CD} 103^{+}$

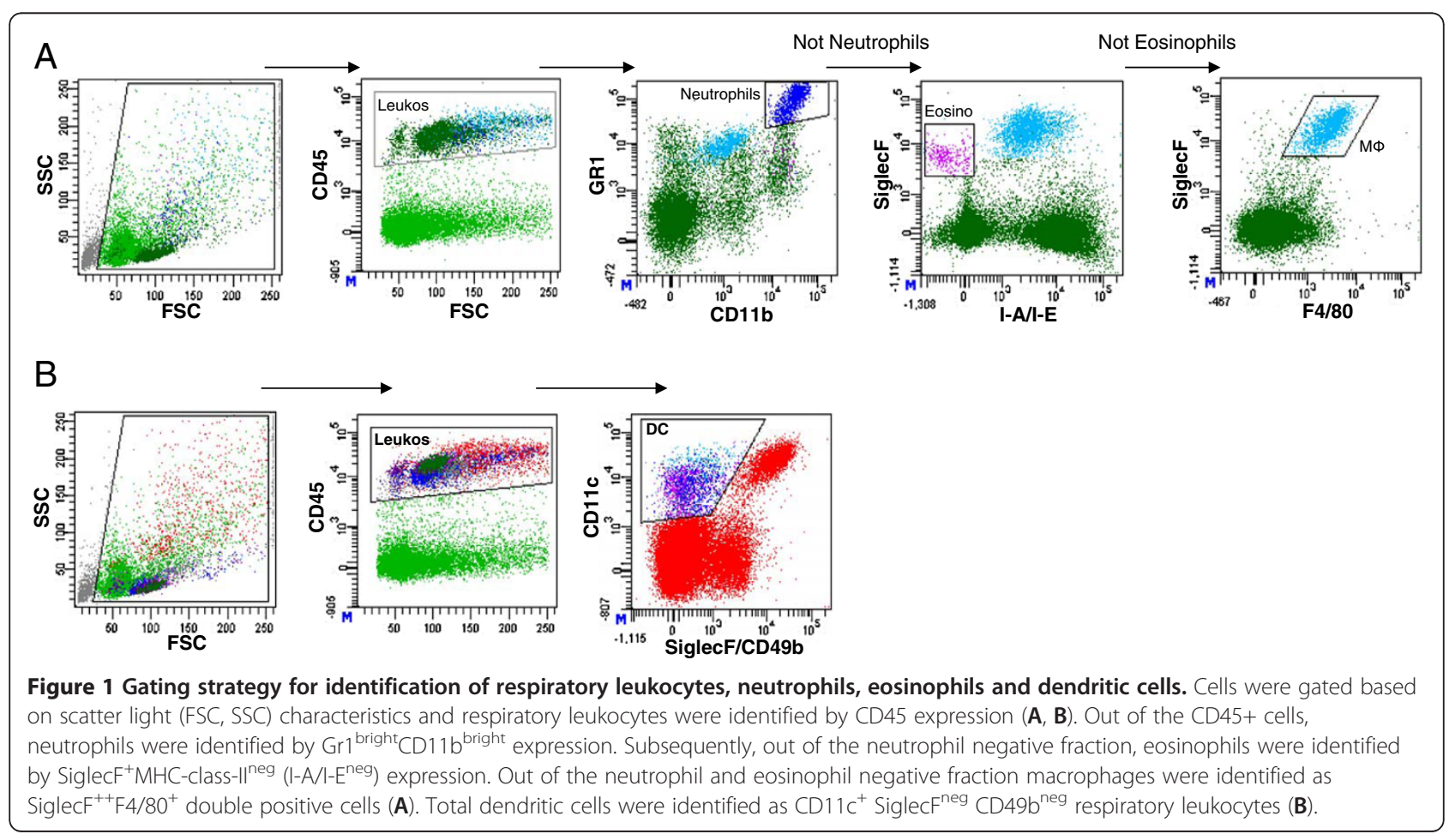




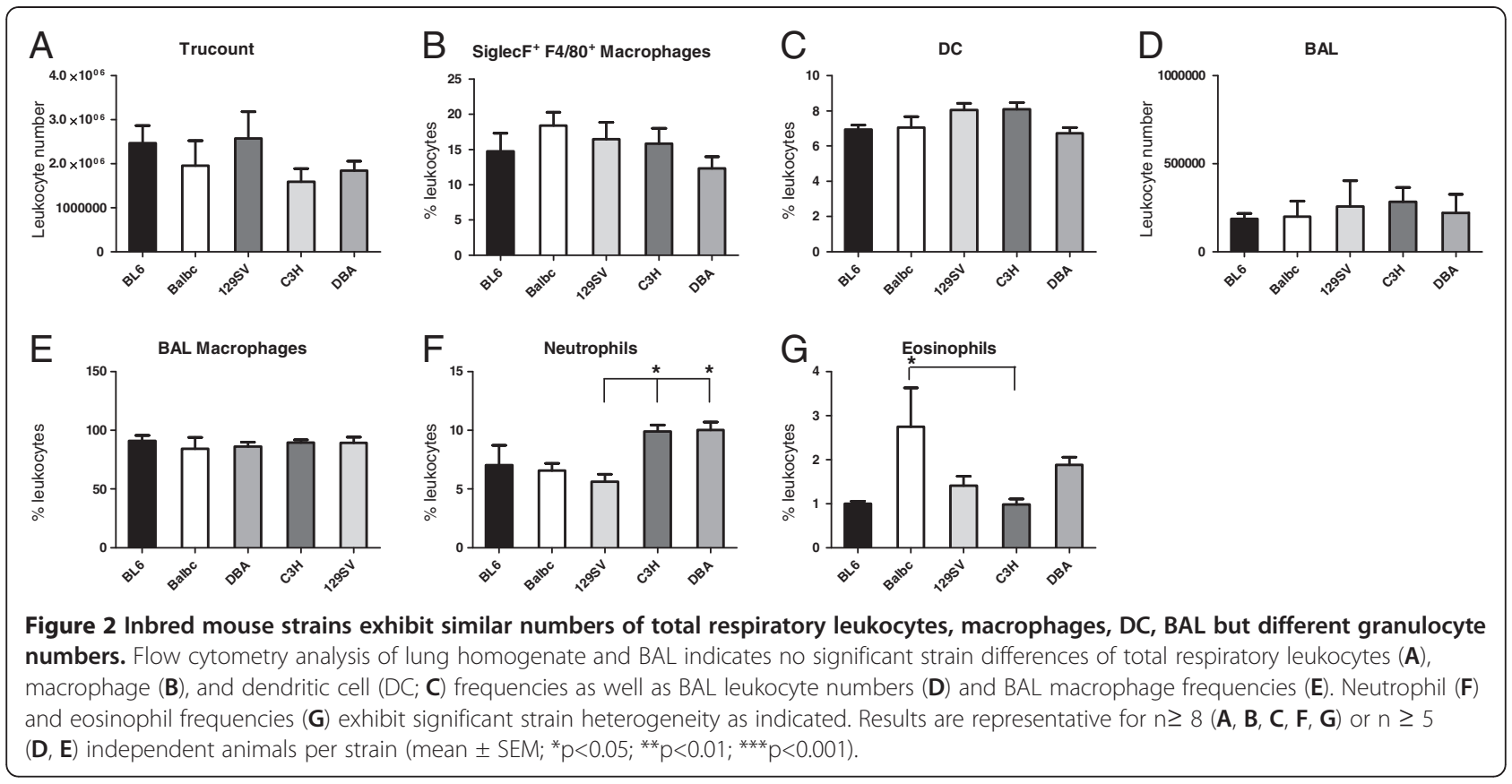

DC and MoDC. Magnitude of DC subset fold-differences for all strains in comparison to C57BL/6 mice is summarized in Table 2.

\section{Inbred mouse strains show marked differences of respiratory $T$ and $B$ cells, innate lymphocytes and $\operatorname{Lin}^{\text {neg }}$ leukocytes}

Classical $\mathrm{B}$ and $\mathrm{T}$ lymphocyte subsets were identified after multiparameter gating for standard surface markers (Figure 5). The two major innate lymphocyte subsets NK cells and $\gamma \delta \mathrm{TCR}+$ lymphocytes were identified according to $\mathrm{CD} 49 \mathrm{~b}\left(\mathrm{CD} 3^{\text {neg }} \mathrm{CD} 49 \mathrm{~b}^{+}\right)$and $\gamma \delta \mathrm{TCR}$ expression $\left(\mathrm{CD}^{\mathrm{pos}} \gamma \delta \mathrm{TCR}^{+}\right)$, respectively (Figure 5$)$. The NK1.1 $\mathrm{mAb}$ was not selected to identifiy NK cells, because the antigen is not expressed on BALB/c, DBA, C3H and 129SV mice. Classical CD3+ T cells as well as CD4+ T helper cell numbers were significantly elevated in BALB/c mice when compared to $\mathrm{C} 57 \mathrm{BL} / 6, \mathrm{C} 3 \mathrm{H}$ or DBA mice, whereas CD8+ T cells showed no major strain differences (Figure 6A-C). CD4+CD25+ putative Treg cell numbers were significantly reduced in C57BL/6 mice when compared to either BALB/c or 129SV mice (Figure 6D). Since CD4+CD25+ T cells are not proven Treg cells, we performed additional analyses of Foxp3+ Treg subsets (please see detailed data at the end of results).

With respect to respiratory $\mathrm{B}$ cells, C57BL/6 mice exhibited significant elevation of respiratory CD19+ lymphocyte numbers when compared to any other inbred mouse strain (Figure 6E). Flow cytometry analysis revealed significantly elevated NK cell numbers in $\mathrm{C} 3 \mathrm{H}$ mice versus $\mathrm{C} 57 \mathrm{BL} / 6, \mathrm{BALB} / \mathrm{c}$ and $129 \mathrm{SV}$ mice (Figure 6F). With respect to respiratory $\gamma \delta \mathrm{T}$ cells, $\mathrm{C} 3 \mathrm{H}$ mice also exhibited the highest numbers, but strain heterogeneity was less pronounced (Figure 6G). Lin ${ }^{\text {neg }}$ respiratory leukocytes were stratified according to CD90 expression and showed also strain heterogeneity (Figure 6 $\mathrm{H}, \mathrm{I})$. The highest $\mathrm{Lin}^{\text {neg }} \mathrm{CD} \mathrm{CO}^{+}$leukocyte numbers were detectable in BALB/c mice $(2.1 \% \pm 0.1)$ and the lowest numbers in DBA mice $(0.7 \% \pm 0.07 ; \mathrm{p}<0.001)$. In contrast, $\mathrm{Lin}^{\text {neg }} \mathrm{CD} 90^{\text {neg }}$ leukocyte numbers elevated in $\mathrm{C} 3 \mathrm{H}$ mice $(1.2 \% \pm 0.22)$ and decreased in C57BL/6 mice $(0.3 \% \pm 0.12 ; \mathrm{p}<0.001)$. These results indicated marked strain heterogeneity of respiratory lymphocytes and innate leukocyte numbers with major differences between C57BL/6, BALB/c and 129 SV mice. Lungs of C57BL/6 mice can be characterized as B cell "rich", whereas $\mathrm{BALB} / \mathrm{c}$ and 129SV mice are rich in T cells. With respect to innate lymphocytes, $\mathrm{C} 3 \mathrm{H}$ and $\mathrm{DBA}$ mice can be characterized as rich in NK cells and $\gamma \delta \mathrm{T}$ cells. Magnitude of lymphocyte subset fold-differences in comparison to C57BL/6 mice is summarized in Table 2.

\section{Cytokine production after stimulation of respiratory leukocytes from inbred mouse strains}

Given the different composition of respiratory leukocyte subsets we questioned whether TNF- $\alpha$ (Figure 7A), IFN- $\gamma$ (Figure 7B) and IL-10 (Figure 7C) production of respiratory leukocytes also exhibited strain heterogeneity. To address different pathways and cell types we stimulated respiratory $\mathrm{T}$ lymphocytes via $\mathrm{CD} 3 / \mathrm{CD} 28 \mathrm{mAbs}$ and TLR4 and TLR9 expressing leukocytes via their specific ligands, LPS and CpG ODN. Results indicated that BALB/ $c$ mice produced significantly higher amounts of TNF- $\alpha$ both after $\mathrm{T}$ cell stimulation and after LPS stimulation 
Table 2 Fold differences of respiratory leukocyte subset frequencies in comparison to C57BL/6 mice ${ }^{1}$

\begin{tabular}{|c|c|c|c|c|}
\hline Subset & BALB/c ( \pm SEM) & $\mathrm{DBA} / 2( \pm \mathrm{SEM})$ & C3H ( \pm SEM) & 129SV ( \pm SEM) \\
\hline CD45+ leukocytes & $0,792(0,22)$ & $0,746(0,08)$ & $1,043(0,24)$ & $0,643(0,12)$ \\
\hline Siglec $\mathrm{F}^{+} \mathrm{F} 4 / 80^{+}$macrophages & $1,249(0,12)$ & $0,837(0,11)$ & $1,075(0,14)$ & $1,117(0,16)$ \\
\hline Neutrophils & $0,935(0,08)$ & $1,428(0,09)$ & $1,406(0,08)$ & $0,799(0,09)$ \\
\hline Eosinophils & $2,742(0,88)$ & $1,882(0,17)$ & $0,980(0,12)$ & $1,407(0,21)$ \\
\hline \multicolumn{5}{|l|}{ Dendritic cell (DC) subsets } \\
\hline DC & $1,015(0,08)$ & $0,968(0,04)$ & $1,165(0,05)$ & $1,159(0,05)$ \\
\hline Plasmacytoid DC & $0,954(0,04)$ & $0,948(0,06)$ & $0,889(0,13)$ & $3,423(0,42)$ \\
\hline CD $103^{+} \mathrm{DC}$ & $1,206(0,11)$ & $0,723(0,08)$ & $1,643(0,15)$ & $0,669(0,08)$ \\
\hline Monocytic DC & $0,935(0,10)$ & $0,962(0,05)$ & $1,551(0,11)$ & $1,134(0,08)$ \\
\hline CD11b $b^{\text {hi }}$ C & $0,914(0,10)$ & $0,824(0,13)$ & $0,798(0,02)$ & $1,543(0,16)$ \\
\hline \multicolumn{5}{|l|}{ Classical lymphocytes } \\
\hline $\mathrm{CD}^{+} \mathrm{T}$ cells & $1,277(0,03)$ & $0,967(0,04)$ & $0,830(0,04)$ & $1,154(0,09)$ \\
\hline $\mathrm{CD}^{+} \mathrm{CD}^{+} \mathrm{T}$ helper cells & $1,649(0,07)$ & $1,093(0,07)$ & $0,959(0,05)$ & $1,399(0,12)$ \\
\hline $\mathrm{CD}^{+} \mathrm{CD}^{+} \mathrm{T}$ cells & $0,894(0,03)$ & $0,691(0,03)$ & $0,683(0,03)$ & $0,786(0,06)$ \\
\hline $\mathrm{CD} 4^{+} \mathrm{CD} 25^{+} \mathrm{T}$ cells & $1,489(0,04)$ & $1,291(0,10)$ & $1,085(0,11)$ & $1,626(0,18)$ \\
\hline CD19 ${ }^{+}$B cells & $0,557(0,12)$ & $0,715(0,06)$ & $0,446(0,02)$ & $0,504(0,05)$ \\
\hline \multicolumn{5}{|c|}{ Innate lymphocytes and Lin ${ }^{\text {neg }}$ leukocytes } \\
\hline CD49b ${ }^{+}$NK cells & $0,859(0,07)$ & $1,127(0,06)$ & $1,270(0,03)$ & $0,633(0,03)$ \\
\hline $\mathrm{TCR} y \delta^{+} \mathrm{T}$ cells & $1,164(0,05)$ & $1,636(0,08)$ & $1,557(0,18)$ & $1,450(0,09)$ \\
\hline $\mathrm{Lin}^{\text {neg }} \mathrm{CD} 45^{+} \mathrm{CD} \mathrm{O}^{+}$innate cells & $1,480(0,08)$ & $0,540(0,05)$ & $0,977(0,07)$ & $1,194(0,26)$ \\
\hline Lin $^{\text {neg }} C D 45^{+} C D 90^{\text {neg }}$ innate cells & $2,034(0,14)$ & $2,185(0,50)$ & $3,673(0,66)$ & $1,573(0,46)$ \\
\hline \multicolumn{5}{|l|}{ T regulator cell populations } \\
\hline $\mathrm{CD}^{+} \mathrm{CD}^{2} 5^{\text {high }} \mathrm{T}$ cells & $1,179(0,05)$ & $0,545(0,02)$ & $0,596(0,02)$ & $1,014(0,04)$ \\
\hline $\mathrm{CD}^{+} \mathrm{CD}^{\text {high }} \mathrm{Foxp}^{+}$Treg cells & $1,089(0,05)$ & $0,536(0,02)$ & $0,602(0,02)$ & $0,986(0,04)$ \\
\hline $\mathrm{CD}^{+} \mathrm{CD} 25^{\text {high }} \mathrm{CD} 9^{+} \mathrm{Foxp}^{+}$Treg cells & $2,000(0,11)$ & $0,959(0,05)$ & $1,250(0,07)$ & $1,656(0,10)$ \\
\hline $\mathrm{CD}^{+} \mathrm{CD} 25^{+} \mathrm{CD} 127^{\mathrm{lo/neg}}$ Treg cells & $1,263(0,06)$ & $0,535(0,04)$ & $0,660(0,03)$ & $1,154(0,07)$ \\
\hline \multicolumn{5}{|l|}{ BAL cells } \\
\hline BAL leukocytes & $1,071(0,47)$ & $1,189(0,55)$ & $1,525(0,43)$ & $1,381(0,78)$ \\
\hline BAL macrophages & $0,926(0,10)$ & $0,945(0,04)$ & $0,983(0,02)$ & $0,981(0,05)$ \\
\hline
\end{tabular}

${ }^{1}$ Results are representative for $\mathrm{n} \geq 5$ (Lin ${ }^{\text {neg }}$ subsets; BAL cells, Treg subsets) or $\mathrm{n} \geq 8$ (all other subsets) independent animals per strain.

than any other strain (Figure 7A). In contrast, after TLR9 stimulation TNF- $\alpha$ production showed no significant strain heterogeneity. IFN- $\gamma$ production was significantly elevated in BALB/c mice versus C57BL/6 mice after T cell stimulation (Figure 7B). With respect to the antiinflammatory cytokine IL-10, BALB/c mice produced significantly more IL-10 after $\mathrm{T}$ cell stimulation than any other strain (Figure 7C). In contrast, after TLR9 stimulation C57BL/6 mice produced significantly more IL-10 in comparison to BALB/c mice. These results indicated that strain heterogeneity exists also with respect to cytokine production capacity. Respiratory leukocytes from BALB/c mice showed a trend towards high cytokine production whereas DBA mice in most of the experiments produced low cytokine levels.
Significant differences of respiratory Foxp $3^{+}$Treg cells across inbred mouse strains

Given the increased numbers $\mathrm{CD} 4^{+} \mathrm{CD}_{2} 5^{+}$in $\mathrm{BALB} / \mathrm{C}$ and $129 \mathrm{SV}$ mice we questioned whether these cells represented Treg cells and extended our analysis. Based on CD25, Foxp3, CD39 and CD127 expression we analysed the following four Treg subsets: $\mathrm{CD} 4^{+} \mathrm{CD} 25^{\text {high }}$, $\mathrm{CD}^{+}{ }^{+} \mathrm{CD} 25^{\text {high }}$ Foxp $^{+}, \mathrm{CD}^{+}{ }^{+} \mathrm{CD} 25^{\text {high }} \mathrm{Foxp}^{+} \mathrm{CD} 9^{+}$ (Figure $8 \mathrm{~A}$ ) and $\mathrm{CD} 4^{+} \mathrm{CD} 25^{+} \mathrm{CD} 127^{\text {low/neg }}$ (Figure $8 \mathrm{~B}$ ) Treg populations. Foxp $3^{+}$expression of the $\mathrm{CD} 4^{+} \mathrm{CD} 25^{+}$ CD $127^{\text {low/neg }}$ Tregs was controlled by intracellular staining and found to be $>90 \%$ positive (Figure $8 \mathrm{~B}$ ). Quantitative results indicated that $\mathrm{BALB} / \mathrm{c}$ and $129 \mathrm{SV}$ strains exhibited significantly higher numbers of $\mathrm{CD} 4^{+} \mathrm{CD} 25^{\text {high }}$, $\mathrm{CD}^{+} \mathrm{CD} 25^{\text {high }}$ Foxp $^{+}$and $\mathrm{CD} 4^{+} \mathrm{CD} 25^{+} \mathrm{CD} 127^{\text {low/neg }}$ 

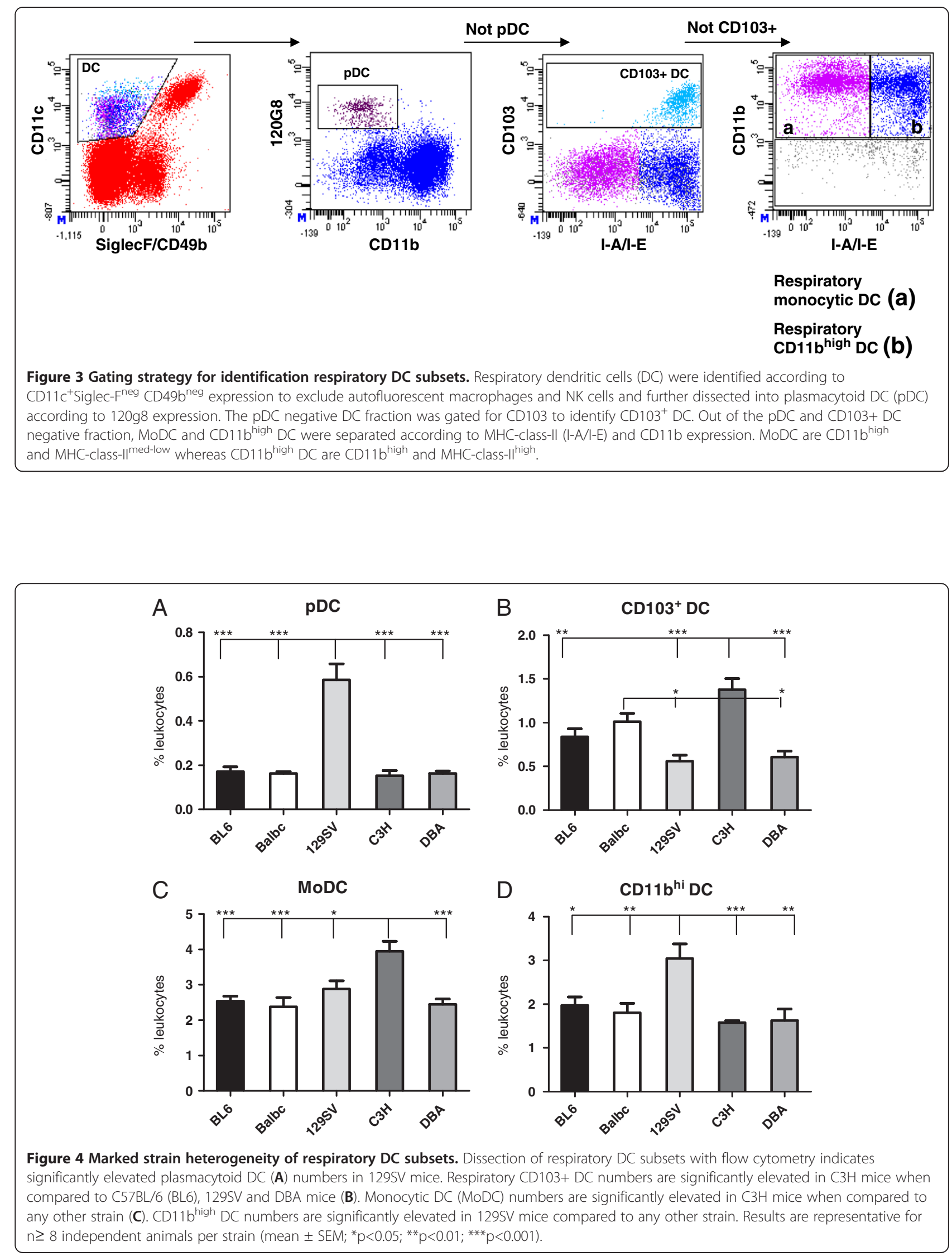


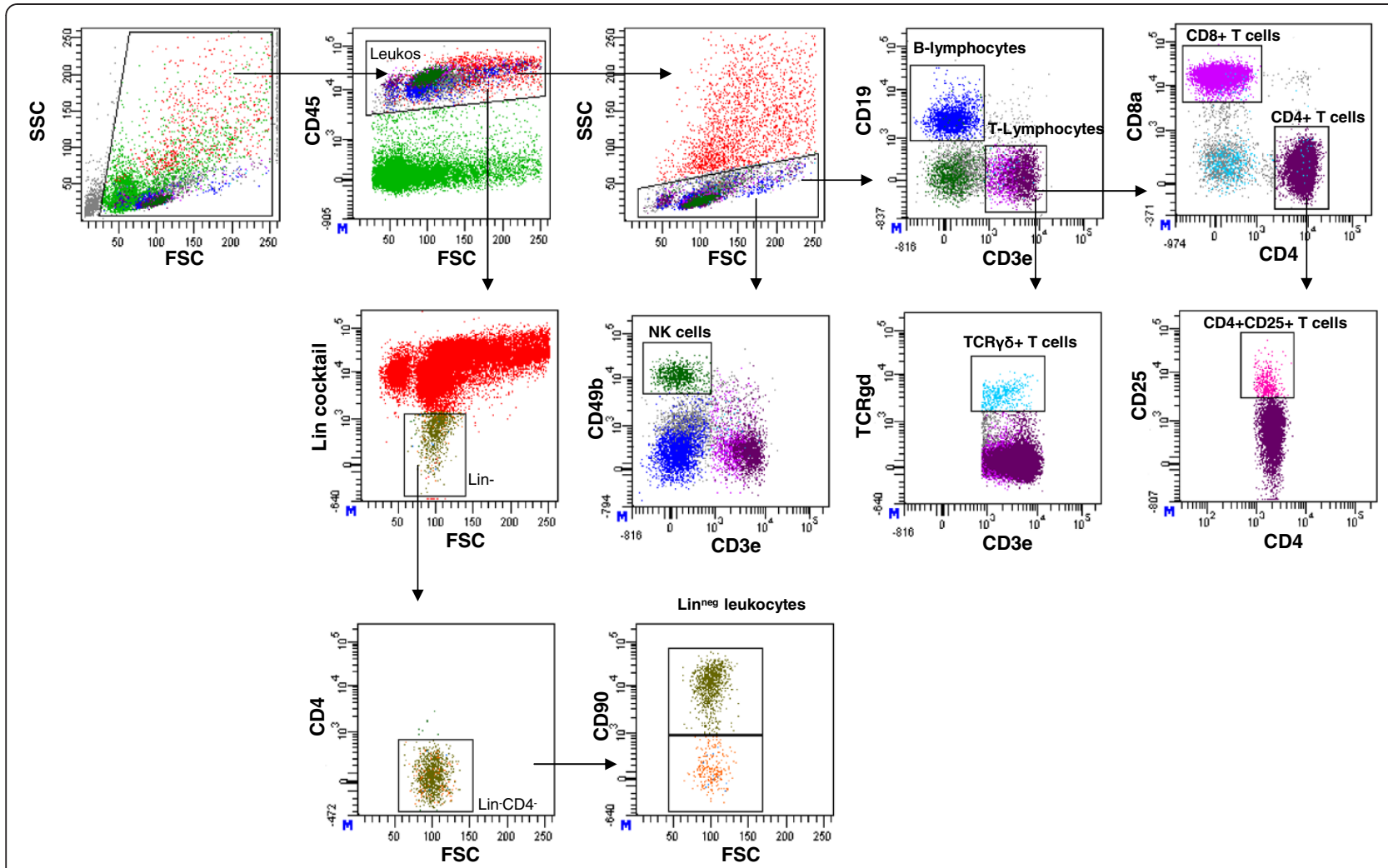

Figure 5 Gating strategy for identification of respiratory lymphocyte subsets and Lin $^{\text {neg }}$ leukocytes. Respiratory B and T lymphocytes were identified according to low side scatter characteristics, CD19 and CD3e surface expression. This gating strategy resulted also in exclusion of autofluorescent respiratory macrophages. Out of the CD3e-positive population CD4+ T helper, $C D 4^{+} \mathrm{CD} 25^{+} \mathrm{T}$ helper and CD8 $\mathrm{T}$ cells were gated according to staining with the respective mAbs and $\gamma \delta T$ cells were identified by using a $\gamma \delta T C R \mathrm{mAb}$. Please note that the $C D 4^{+} C D 25^{+} T$ cells are not CD25 high. A more detailed gating strategy of Treg subsets including isotpye controls is shown in Figure 8. Natural killer cells were identified according to $\mathrm{CD} 49 \mathrm{~b}^{+} \mathrm{Cd} 3 \mathrm{e}^{\text {neg }}$ expression. Respiratory lineage-negative leukocytes were identified by absence of CD3e, CD8a, CD11b, CD11C, CD19, B220, TER-119, FceR1 (Lineage cocktail) and CD4 expression and subsequently separated into CD90 and CD90 ${ }^{\text {neg }}$ cells.

Tregs in comparison to $\mathrm{C} 3 \mathrm{H}$ and DBA strains (Figure 9 A-D). C57BL/6 mice exhibited similar Treg numbers in comparison to $\mathrm{BALB} / \mathrm{c}$ mice with the exception of the $\mathrm{CD}^{+} \mathrm{CD}^{25^{\text {high }}}$ Foxp3 $^{+} \mathrm{CD} 9^{+}$and $\mathrm{CD} 4^{+} \mathrm{CD} 25^{+}$ $\mathrm{CD} 127^{\text {low/neg }}$ populations (Figure $9 \mathrm{C}, \mathrm{D}$ ). Magnitude of Treg subset fold-differences in comparison to C57BL/6 mice is summarized in Table 2.

\section{Discussion}

In this report we demonstrate marked strain heterogeneity of respiratory leukocyte subsets in five major inbred mouse strains. To our knowledge this is the first analysis that has quantitated DC subsets, macrophages, classical lymphocyte subsets, Treg subsets, innate lymphocytes including $\gamma \delta \mathrm{T}$ cells and lin ${ }^{\text {neg }}$ leukocytes in the respiratory tract. Environmental effects are unlikely to account for these differences, since specific-pathogen free agematched animals were received from the same provider and housed under specific-pathogen free conditions. The enumerated leukocyte subsets are essential for different immunological tasks and therefore it is possible that the observed strain heterogeneity influences respiratory immunity to different pathogens.

With respect to respiratory DC subsets we found a striking elevation of respiratory pDC in 129SV mice in comparison to all other strains. These results extend the finding of Asselin-Paturel et al., and Nakano et al. who reported significantly elevated pDC frequencies in spleen and blood of $129 \mathrm{SV}$ mice [20,21]. Since respiratory pDC represent a key DC subset responding to viral infection and additionally play an immunoregulatory role by preventing airway hyperresponsiveness, higher pDC numbers may influence pathogenesis of respiratory allergy and viral infection in 129SV mice versus other strains. With respect to respiratory $\mathrm{CD} 103^{+} \mathrm{DC}$ our results indicated that $\mathrm{C} 3 \mathrm{H}$ mice exhibited significantly higher numbers in comparison to $129 \mathrm{~Sv}$ and DBA mice. Given the critical role of respiratory $\mathrm{CD} 103^{+} \mathrm{DC}$ for activation of naive $\mathrm{CD} 8+\mathrm{T}$ killer cells in respiratory viral infections [5,22], different CD103+ DC numbers may impact the strain-dependent capacity to generate viral $\mathrm{CD} 8^{+} \mathrm{T}$ cell immunity. Moreover, differences have also been reported 


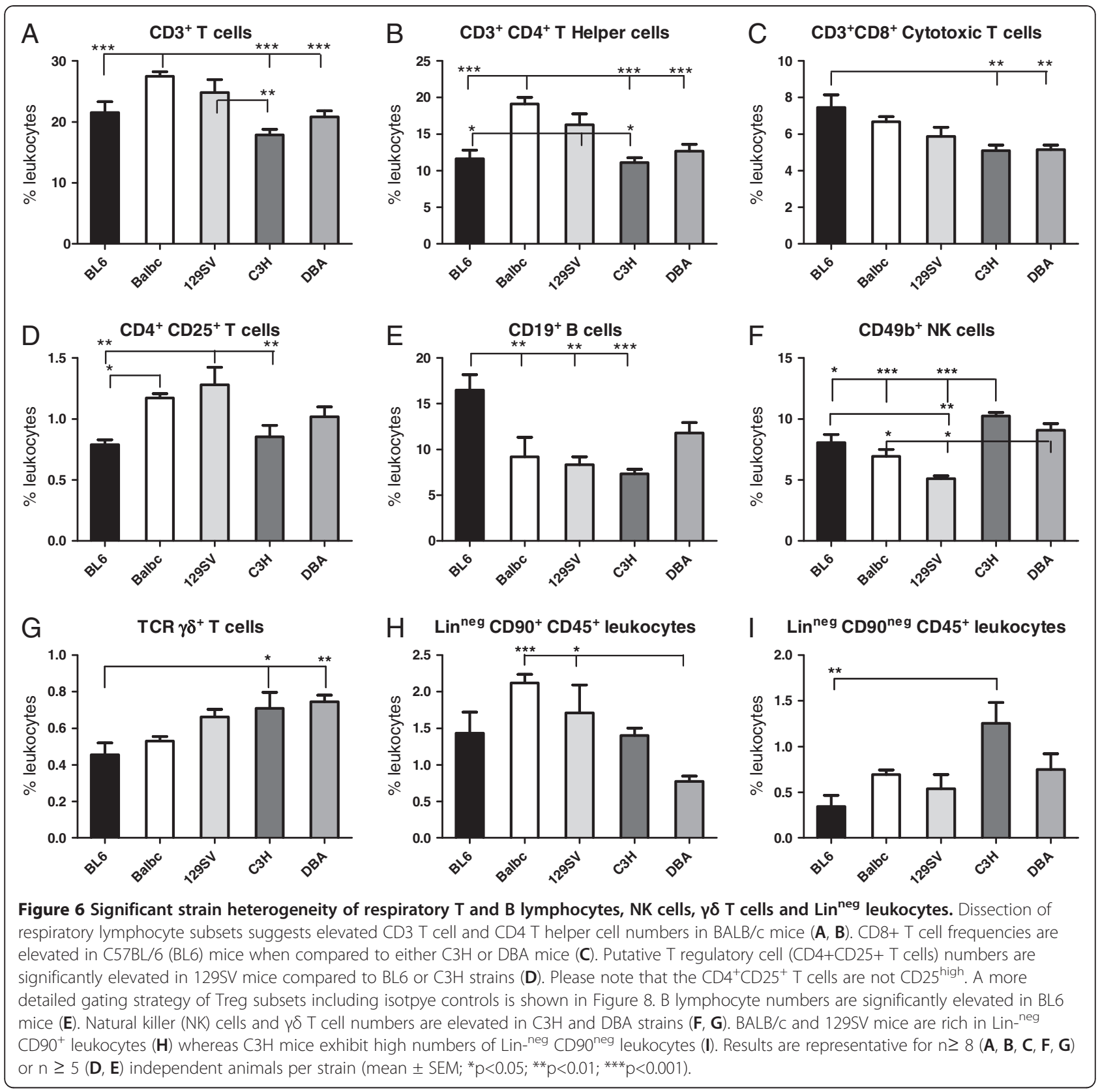

according to DC endocytosis receptor expression, such as mannose receptor [23] and CD207 (langerin, a c-type specific lectin)[24] highlighting separate levels of strain heterogeneity. In line with these reports, our analysis of respiratory leukocytes indicated significant strain differences to produce TNF- $\alpha$ and IL-10 that is partially dependent on the selected Toll-like receptor ligand and the activated leukocyte subset. Our results revealed that respiratory leukocytes of $\mathrm{BALB} / \mathrm{c}$ mice produced the highest TNF- $\alpha$ levels both after TLR4 stimulation through LPS and after T-cell stimulation through CD3/ CD28 mAbs. These results support the finding of Gosselin et al. demonstrating that resistance of BALB/c mice to pseudomonas aeruginosa is dependent on increased TNF- $\alpha$ production [25].

In addition to significant differences of DC subsets and cytokine production capacity we found marked differences of respiratory Foxp $3^{+}$Treg frequencies across different inbred strains. In general terms, $\mathrm{BALB} / \mathrm{c}$ and 129SV mice exhibited significantly higher respiratory Treg numbers than $\mathrm{C} 3 \mathrm{H}$ and $\mathrm{DBA}$ mice. Respiratory Treg elevation was evident with respect to four different Treg subsets, namely $\mathrm{CD} 4^{+} \mathrm{CD} 25^{\text {high }}$, $\mathrm{CD}^{+}{ }^{+} \mathrm{CD} 25^{\text {high }} \mathrm{Foxp}^{+}, \mathrm{CD}^{+} \mathrm{CD} 25^{\text {high }} \mathrm{Foxp}^{+} \mathrm{CD} 39$ and $\mathrm{CD}_{4}^{+} \mathrm{CD} 25^{+} \mathrm{CD} 127^{\text {low/neg }}$ Tregs. Given the important role of Treg in immunoregulation, additional 


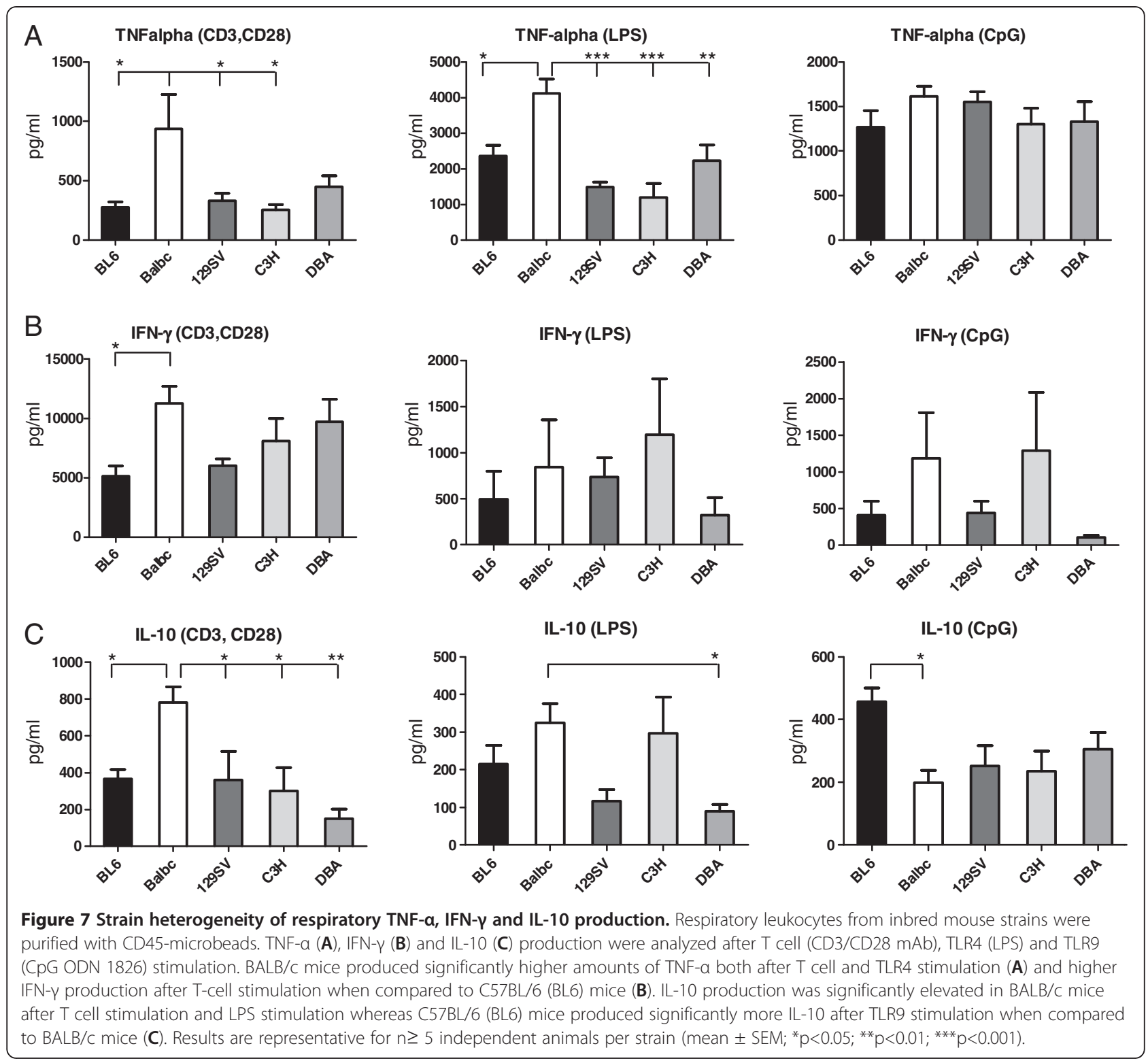

studies are required to dissect the genetic cause und functional relevance of Treg differences in inbred mouse strains.

Both numerical and functional leukocyte strain variabilities are likely to contribute to innate resistance and susceptibility to infection with various pathogens. Examples are the unique susceptibility of DBA/2 mice to pulmonary tuberculosis as well as resistance of $129 \mathrm{S6} / \mathrm{SVevTac}$ mice to salmonella typhimurium infection [26]. Genetic dissection of strain heterogeneity promoted the discovery of several highly relevant immune response genes and modifiers underlining the importance of inbred mouse models to understand innate and adaptive immunity $[26,27]$.

Furthermore, knowledge of significant numerical differences of respiratory leukocyte subsets is also practically relevant for the planning and setup of ex vivo experiments. Several functionally distinct cells, like pDC, represent extremely rare subsets in the lung and therefore ex vivo analysis of sufficient numbers of purified respiratory pDC is technically difficult. Accordingly, our results may help identification of the suitable inbred mouse strain with the highest pDC numbers. Given pDC frequencies in the five major inbred strains ranging from $0.15 \%$ (mean of $\mathrm{C} 3 \mathrm{H}$ mice) to $0.58 \%$ (mean of $129 \mathrm{SV}$ mice) of leukocytes while having similar total leukocyte counts, selection of the 129SV mouse would increase the pDC yield 3 to 4-fold and would save both animal numbers and procedural time. Similar conclusions can be drawn with respect to sorting of rare $\operatorname{Lin}^{\text {neg }}$ leukocytes populations from the lungs for ex vivo experiments. Our 


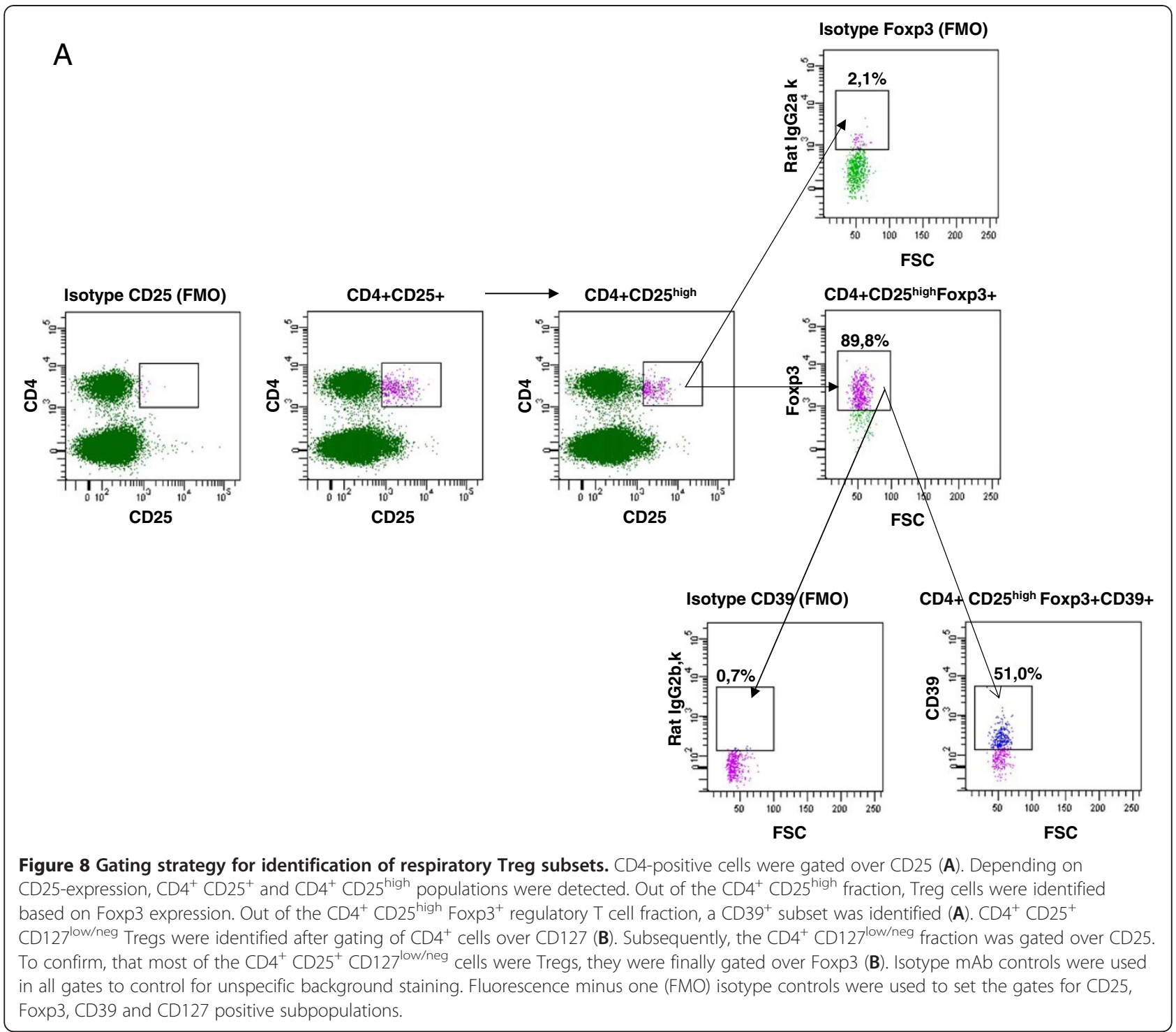

results indicated that C57BL/6 mice have only few Lin ${ }^{\text {neg }}$ $\mathrm{CD} 0^{\text {neg }}$ leukocytes (mean $0.34 \%$ of leukocytes) in comparison to $\mathrm{C} 3 \mathrm{H}$ mice (mean $1.25 \%$ ).

In more general terms, our study indicated characteristic respiratory immunophenotypes of inbred mouse strain: BALB/c mice are rich of eosinophils and Treg cells; C57BL/6 mice are rich of B cells and low in eosinophils. In contrast, 129SV mice are high in pDC and Tregs and $\mathrm{C} 3 \mathrm{H}$ mice are high in $\mathrm{CD}_{103}{ }^{+} \mathrm{DC}$, NK cells and $\gamma \delta \mathrm{T}$ cells. These characteristic immunophenotypes may help the selection of strains for respiratory disease models, e.g. if the analysis and purification of respiratory $\mathrm{pDC}$ during viral pneumonia is required then 129SV mice would be a suitable model. However, besides different respiratory immunophenotypes, many other functionally relevant strain differences have been reported. Therefore, careful strain selection based on disease model and published strain differences may help to select the best mouse strain representing human phenotypes. In this context, DeVooght et al. recently reported, that choice of mouse strain significantly influenced the outcome in a model of chemical-induced asthma. They reported that the human phenotype of chemical-induced asthma was best reproduced in BALB/c when compared to 6 other strains [28].

Inbred mouse strain differences have been reported with respect to different aspects of inflammation. With respect to the respiratory irritant ozone, C57BL/6 mice have been reported relatively susceptible when compared to relatively resistant $\mathrm{C} 3 \mathrm{H}$ mice [29]. With respect to chronic pseudomonas aeruginosa infection, BALB/c mice are resistant in comparison to highly susceptible DBA/2 mice [30]. Similarly, in a pneumovirus model, $\mathrm{BALB} / \mathrm{c}$ and $\mathrm{C} 57 \mathrm{BL} / 6$ strains were reported to be 

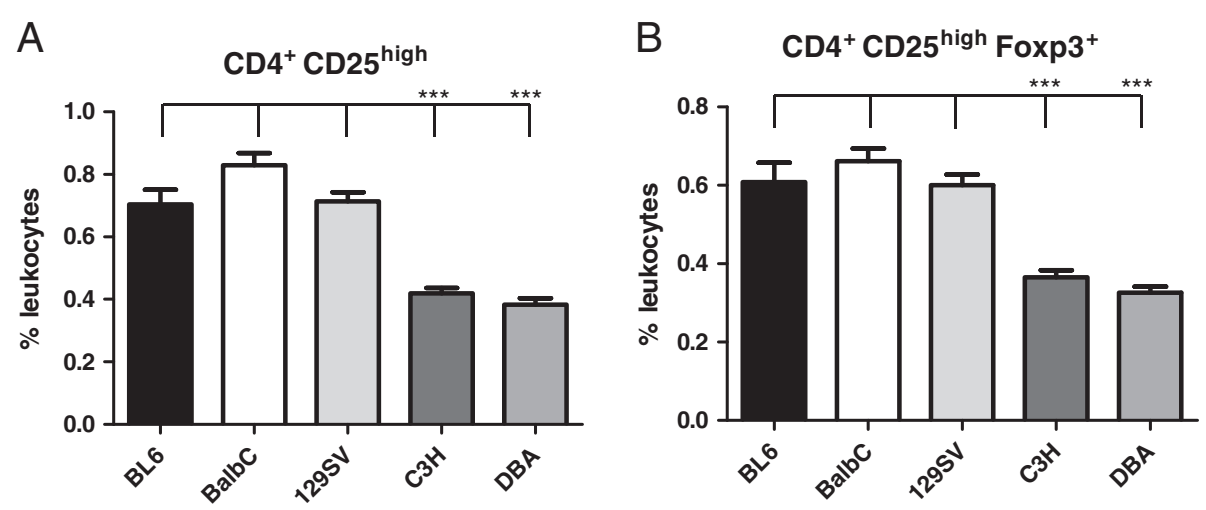

C $\quad \mathrm{CD}^{+} \mathrm{CD}^{\mathrm{C} 5^{\mathrm{high}}} \mathrm{Foxp}^{+} \mathrm{CD} 39^{+}$
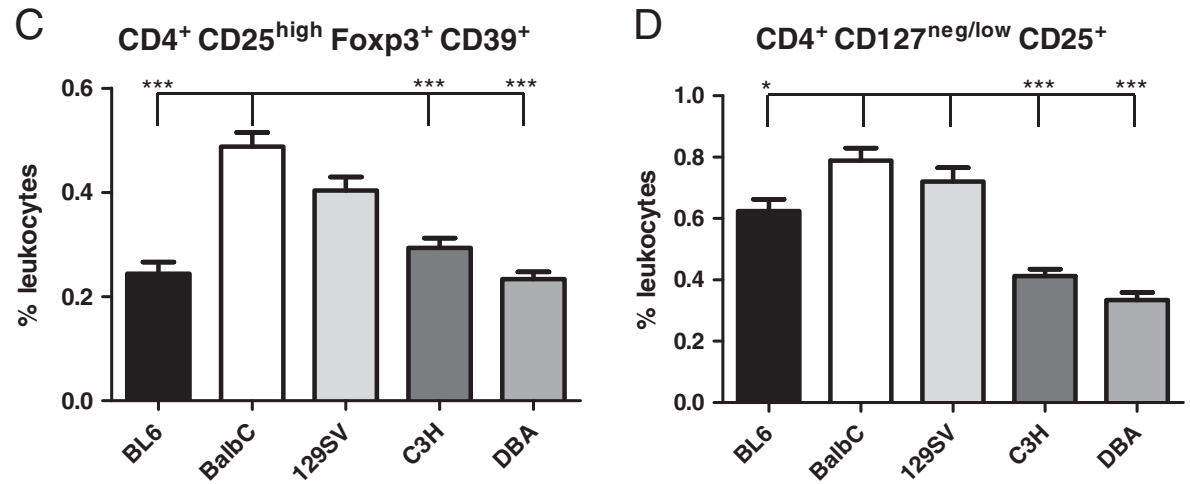

Figure 9 Inbred mouse strains exhibit different numbers of respiratory Treg cells. Analysis of Treg populations according to CD25, Foxp3, CD39 and CD127 expression indicates significantly increased CD4 $4^{+}$CD25 ${ }^{\text {high }}(\mathbf{A}), \mathrm{CD}^{+}$CD25 $5^{\text {high }}$ Foxp3 $3^{+}(\mathbf{B}), \mathrm{CD}^{+} \mathrm{CD}^{2} 5^{\text {high }}$ Foxp3 $^{+} \mathrm{CD} 9^{+}(\mathbf{C})$, and $\mathrm{CD}^{+} \mathrm{CD}^{+} 5^{+} \mathrm{CD} 127^{\text {low/neg }}$ (D) Treg subsets in BALB/c mice in comparison to $\mathrm{C} 3 \mathrm{H}$ and DBA mice. Results are representative for $\mathrm{n} \geq 5$ independent animals per strain (mean $\pm \mathrm{SEM} ;{ }^{*} p<0.05 ;{ }^{* * *} p<0.001$ ).

relatively resistant in comparison to $\mathrm{DBA} / 2$ or $129 \mathrm{SV}$ mice [31].

In summary, the present study highlights marked numerical differences of several important leukocytes subsets in the lungs of major inbred mouse strains. Although our results are primarily descriptive, it may provide the basis for additional functional studies under inflammatory in vivo conditions. Variation of respiratory immune responses and cytokine production capacity may partially be related to strain differences in respiratory leukocyte composition and function.

\section{Competing interests}

The authors declare that they have no competing interests.

\section{Authors' contributions}

$\mathrm{HH}$ designed research, analyzed and interpreted data and wrote the manuscript; AW, NB, SK performed research, analyzed and interpreted data; $J \mathrm{~L}$ and $\mathrm{GB}$ interpreted data and critically read the manuscript. All authors have read and approved the final manuscript.

\section{Acknowledgements}

The work was supported by the SFB Transregio 84, German Science Foundation, Innate Immunity of the Lung: Mechanisms of Pathogen Attack and Host Defence in Pneumonia (SFB TR84, Project B3 HH, JL). Additional support was provided by UGMLC (University Gießen and Marburg Lung Center) and Excellence Cluster Cardiopulmonary System (ECCPS). The authors thank Gabriela Haley for technical assistance.

\section{Author details}

'Institute for Clinical Immunology and Transfusion Medicine, Justus-Liebig-University Giessen, Member of the German Center for Lung Research, Langhansstr 7, D-35390, Giessen, Germany. ${ }^{2}$ Department of Internal Medicine II, University of Giessen Lung Center, Klinikstrasse 36, D-35392, Giessen, Germany.

Received: 9 January 2012 Accepted: 17 August 2012

Published: 15 October 2012

\section{References}

1. Curotto Lafaille MA D, Lafaille JJ, Graca L: Mechanisms of tolerance and allergic sensitization in the airways and the lungs. Curr Opin Immunol 2010, 22:616-622.

2. Steinman R, Banchereau J: Taking dendritic cells into medicine. Nature 2007, 449:419-426.

3. Hackstein $H$, Thomson A: Dendritic cells: emerging pharmacological targets of immunosuppressive drugs. Nat Rev Immunol 2004, 4:24-34.

4. Banchereau J, Briere F, Caux C, Davoust J, Lebecque S, Liu YJ, Pulendran B, Palucka K: Immunobiology of dendritic cells. Annu Rev Immunol 2000, 18:767-811.

5. Kim T, Braciale T: Respiratory dendritic cell subsets differ in their capacity to support the induction of virus-specific cytotoxic CD8+ T cell responses. PLoS One 2009, 4:e4204.

6. Hammad H, Lambrecht BN: Dendritic cells and airway epithelial cells at the interface between innate and adaptive immune responses. Allergy 2011, 66:579-587.

7. Hao X, Kim T, Braciale T: Differential response of respiratory dendritic cell subsets to influenza virus infection. J Virol 2008, 82:4908-4919. 
8. Smit J, Rudd B, Lukacs N: Plasmacytoid dendritic cells inhibit pulmonary immunopathology and promote clearance of respiratory syncytial virus. J Exp Med 2006, 203:1153-1159.

9. Wang H, Peters N, Schwarze J: Plasmacytoid dendritic cells limit viral replication, pulmonary inflammation, and airway hyperresponsiveness in respiratory syncytial virus infection. J Immunol 2006, 177:6263-6270.

10. de Heer HJ, Hammad H, Soullie T, Hijdra D, Vos N, Willart M, Hoogsteden H, Lambrecht B: Essential role of lung plasmacytoid dendritic cells in preventing asthmatic reactions to harmless inhaled antigen. J Exp Med 2004, 200:89-98.

11. Sung S, Fu S, Rose C, Gaskin F, Ju S, Beaty S: A major lung CD103 (alphaE)-beta7 integrin-positive epithelial dendritic cell population expressing Langerin and tight junction proteins. J Immunol 2006, 176:2161-2172.

12. Le B, Etchart N, Goubier A, Lira S, Sirard J, Van R, Caux C, Ait-Yahia S, Vicari $A$, Kaiserlian D, Dubois B: Dendritic cells rapidly recruited into epithelial tissues via CCR6/CCL20 are responsible for CD8+ T cell crosspriming in vivo. Immunity 2006, 24:191-201

13. Leon B, Lopez-Bravo M, Ardavin C: Monocyte-derived dendritic cells formed at the infection site control the induction of protective $T$ helper 1 responses against Leishmania. Immunity 2007, 26:519-531.

14. Furuhashi $K$, Suda T, Hasegawa H, Suzuki Y, Hashimoto D, Enomoto N, Fujisawa T, Nakamura Y, Inui N, Shibata K, Nakamura H, Chida K: Mouse Lung CD103+ and CD11bhigh dendritic cells preferentially induce distinct CD4+ T cell responses. Am J Resp Cell Mol Biol 2012, 46:165-172.

15. Ho AWS, Prabhu N, Betts RJ, Ge MQ, Dai X, Hutchinson PE, Lew FC, Wong KL, Hanson BJ, Macary PA, Kemeny DM: Lung CD103+ Dendritic Cells Efficiently Transport Influenza Virus to the Lymph Node and Load Viral Antigen onto MHC Class I for Presentation to CD8 T Cells. J Immunol 2011, 187:6011-6021.

16. Kim T, Hufford M, Sun J, Fu Y, Braciale T: Antigen persistence and the control of local T cell memory by migrant respiratory dendritic cells after acute virus infection. J Exp Med 2010, 207:1161-1172.

17. Neill DR, Wong SH, Bellosi A, Flynn RJ, Daly M, Langford TKA, Bucks C, Kane CM, Fallon PG, Pannell R, Jolin HE, McKenzie ANJ: Nuocytes represent a new innate effector leukocyte that mediates type-2 immunity. Nature 2010, 464:1367-1370.

18. Barlow J, Bellosi A, Hardman C, Drynan L, Wong S, Cruickshank J, McKenzie A: Innate IL-13-producing nuocytes arise during allergic lung inflammation and contribute to airways hyperreactivity. J Allergy Clin Immunol 2012, 129:191-198.

19. Maus U, Herold S, Muth H, Maus R, Ermert L, Ermert M, Weissmann N, Rosseau S, Seeger W, Grimminger F, Lohmeyer J: Monocytes recruited into the alveolar air space of mice show a monocytic phenotype but upregulate CD14. Am J Physiol Lung Cell Mol Physiol 2001, 280:L58-L68.

20. Asselin-Paturel C, Brizard G, Pin J, Briere F, Trinchieri G: Mouse strain differences in plasmacytoid dendritic cell frequency and function revealed by a novel monoclonal antibody. J Immunol 2003, 171:6466-6477.

21. Nakano H, Yanagita M, Gunn MD: CD11C(+)B220(+)Gr-1(+) cells in mouse lymph nodes and spleen display characteristics of plasmacytoid dendritic cells. J Exp Med 2001, 194:1171-1178.

22. Beauchamp NM, Busick RY, Alexander-Miller MA: Functional Divergence among CD103+ Dendritic Cell Subpopulations following Pulmonary Poxvirus Infection. J Virol 2010, 84:10191-10199.

23. Autenrieth $\mathrm{S}$, Autenrieth I: Variable antigen uptake due to different expression of the macrophage mannose receptor by dendritic cells in various inbred mouse strains. Immunology 2009, 127:523-529.

24. Flacher V, Douillard P, Ait-Yahia S, Stoitzner P, Clair-Moninot V, Romani N, Saeland S: Expression of langerin/CD207 reveals dendritic cell heterogeneity between inbred mouse strains. Immunology 2008, 123:339-347.

25. Gosselin D, DeSanctis J, Boule M, Skamene E, Matouk C, Radzioch D: Role of tumor necrosis factor alpha in innate resistance to mouse pulmonary infection with Pseudomonas aeruginosa. Infect Immun 1995, 63:3272-3278

26. Lam-Yuk-Tseung S, Gros P: Genetic control of susceptibility to bacterial infections in mouse models. Cell Microbiol 2003, 5:299-313.

27. Gruenheid S, Gros P: Forward genetic dissection of innate response to infection in inbred mouse strains: selected success stories. Clin Exp Immunol 2010, 162:393-401.
28. de Vooght V, Vanoirbeek JAJ, Luyts K, Haenen S, Nemery B, Hoet PHM: Choice of mouse strain influences the outcome in a mouse model of chemical-induced asthma. PLoS One 2010, 5:e12581.

29. Broeckaert F, Clippe A, Wattiez R, Falmagne P, Bernard A: Lung hyperpermeability, Clara-cell secretory potein (CC16), and susceptibility to ozone of five inbred strains of mice. Inhal Toxicol 2003, 15:1209-1230.

30. Stotland PK, Radzioch D, Stevenson MM: Mouse models of chronic lung infection with Pseudomonas aeruginosa: models for the study of cystic fibrosis. Pediatr Pulmonol 2000, 30:413-424.

31. Anh DBT, Faisca P, Desmecht DJ: Differential resistance/susceptibility patterns to pneumovirus infection among inbred mouse strains. Am J Physiol Lung Cell Mol Physiol 2006, 291:L426-L435.

doi:10.1186/1465-9921-13-94

Cite this article as: Hackstein et al.: Heterogeneity of respiratory dendritic cell subsets and lymphocyte populations in inbred mouse strains. Respiratory Research 2012 13:94

\section{Submit your next manuscript to BioMed Central and take full advantage of:}

- Convenient online submission

- Thorough peer review

- No space constraints or color figure charges

- Immediate publication on acceptance

- Inclusion in PubMed, CAS, Scopus and Google Scholar

- Research which is freely available for redistribution 